\title{
PERBANDINGAN HASIL ANALISIS SPERMA DARI PROSES COITUS INTERRUPTUS DAN MASTURBASI PADA KASUS INFERTILITAS
}

\section{COMPARISON OF SPERM ANALYSIS FROM COITUS INTERRUPTUS AND MASTURBATION IN INFERTILITY CASE}

\author{
Edy Priyanto $^{1 *}$, Norina Agatri ${ }^{2,3}$, Fitranto Arjadi $^{4}$ \\ ${ }^{1}$ Divisi Fertilitas dan Endokrinologi Reproduksi, Departemen Obstetri dan Ginekologi, \\ Fakultas Kedokteran, Universitas Jenderal Soedirman \\ Jalan Dr.Gumbreg No 1, Purwokerto, Jawa Tengah, Indonesia \\ ${ }^{2}$ Laboratorium Penunjang Infertilitas Rumah Sakit Ibu dan Anak Bunda Arif Purwokerto \\ Jalan Jatiwinangun No 16, Purwokerto Lor, Purwokerto, Jawa Tengah, Indonesia \\ ${ }^{3}$ Magister Ilmu Biomedis, Fakultas Kedokteran, Universitas Jenderal Soedirman \\ Jalan Dr.Gumbreg No 1, Purwokerto, Jawa Tengah, Indonesia \\ ${ }^{4}$ Departemen Anatomi, Fakultas Kedokteran, Universitas Jenderal Soedirman \\ Jalan Dr.Gumbreg No 1, Purwokerto, Jawa Tengah, Indonesia
}

\begin{abstract}
ABSTRAK
Pasangan infertil semakin banyak ditemukan di Indonesia, 40\% penyebab infertilitas terkait dengan faktor suami. Analisis sperma merupakan metode untuk mengetahui penyebab infertilitas. Metode masturbasi lebih direkomendasikan dibandingkan coitus interruptus. Kekurangan pada metode masturbasi adalah adanya beban psikologis dan latar belakang agama. Tujuan penelitian adalah membandingkan hasil analisis sperma dari hasil coitus interruptus dan masturbasi pada kasus infertilitas. Jenis penelitian adalah observasional analitik. Sampel penelitian berjumlah 97 laki-laki infertil yang melakukan pemeriksaan di RSIA Bunda Arif pada bulan Januari 2017 - Juni 2018. Teknik sampling menggunakan total sampling. Analisis sperma menggunakan klasifikasi dari WHO tahun 2010. Analisis statistik yang digunakan adalah uji t tidak berpasangan. Hasil penelitian menunjukkan perbedaan bermakna konsentrasi sperma $(p=0,043)$ pada kelompok masturbasi 46,5 $\pm 7,2$ dan kelompok coitus interruptus $18,7 \pm 5,3$. Hasil yang tidak bermakna pada motilitas $(p=0,632)$ dan morfologi $(p=0,722)$. Kesimpulan penelitian adalah analisis sperma dengan proses masturbasi lebih baik konsentrasinya dibandingkan dengan proses coitus interruptus pada kasus infertilitas.
\end{abstract}

Kata kunci : analisis sperma, coitus interruptus, masturbasi 


\begin{abstract}
Infertile couples are increasingly found in Indonesia and the $40 \%$ of many causes are related to husband factors consequently sperm analysis is needed to predict infertility. A method of masturbation is more recommended than coitus interruptus. The deficiency of masturbation method lies on psychological and religious burden. This research aims at comparing the sperm analysis resulted from coitus interuptus and masturbation in infertility cases. It belongs to observational analityc reserach. The subjects of the research were 97 infertile male patients who underwent examination in RSIA Bunda Arif in January 2017-June 2018 and total sampling method was applied. The sperm analysis utilized WHO classification in 2010 and independent t-test was used in statistics analysis. The results of this study showed the sperm comparison and research results $(\mathrm{p}=0.043)$ in masturbation groups is $46.5 \pm 7.2$ and the coitus interruptus group is $18.7 \pm$ 5.3 and the result is not suitable for motility $(p=0.632)$ and morphology $(p=0.722)$ in spite of the fact that it showed better in the masturbation group. The study concludes that the sperm concentration in sperm analysis in the masturbation process is better and more recommended than that of coitus interruptus.
\end{abstract}

Keyword : coitus interruptus, masturbation, sperm analysis

\title{
Penulis korespondensi:
}

Edy Priyanto

Divisi Fertilitas dan Endokrinologi Reproduksi, Departemen Obstetri dan Ginekologi Fakultas Kedokteran

Universitas Jenderal Soedirman

Jalan Dr. Gumbreg no. 1 Purwokerto, Jawa Tengah, Indonesia

Email: dredypa@ymail.com

\section{PENDAHULUAN}

Sebanyak 60\% kasus infertilitas pada laki-laki diketahui penyebabnya, sedangkan sisanya idiopatik. Walaupun diagnosis dapat ditegakkan tetapi sebagian besar dalam tidak dapat diterapi dan hanya 20\% kasus dapat diobati secara konvensional (Hinting, 2009). Salah satu tahapan penegakan diagnosis infertilitas adalah dengan melakukan analisis sperma. Pemeriksaan analisis sperma meliputi volume, konsentrasi, motilitas sperma dan morfologi. Kriteria hasil analisis sperma yang normal adalah volume 2-6 ml, konsentrasi sperma lebih dari $20 \mathrm{juta} / \mathrm{ml}$, motilitas sperma lurus dan cepat lebih dari $25 \%$ dan morfologi normal lebih dari 30\% (Hinting, 2009).

Hasil pemeriksaan analisis sperma juga membantu menentukan diagnosis infertilitas khususnya konsentrasi, motilitas dan morfologi spermatozoa (Elzanaty \& Malm, 2008). Sperma normal terdiri dari spermatozoa motil dan non-motil serta cairan kental. Teknik pengumpulan/penampungan dan analisis yang tepat dari ejakulat harus dilakukan melalui prosedur standar untuk memberikan informasi yang valid. Keberadaan assisted reproductive technology (ART) harus diimbangi dengan teknik pengumpulan ejakulat terstandar yang menjamin kualitas dan kuantitas spermatozoa untuk menunjang keberhasilan pengobatan infertilitas (Bahyah, 2010). 
Berbagai metode pengumpulan/penampungan semen sudah dikerjakan pada analisis sperma pada program ART yaitu masturbasi, hubungan seksual tidak lengkap (coitus interruptus), dan hubungan seks yang lengkap. WHO (2010) merekomendasikan pengumpulan sperma dengan ejakulasi melalui masturbasi dan tidak dengan coitus interruptus dengan alasan kandungan konsentrasi tertinggi akan hilang saat hubungan seksual (Deghani et al., 2004). WHO (2010) mengakomodasi 4 cara untuk pengumpulan sperma yaitu masturbasi, coitus interruptus, coitus lengkap dengan kondom dan assisted ejaculation secara elektronik menggunakan paraplegics. Spesimen yang diambil harus menyerupai ejakulat yang dikeluarkan selama hubungan seksual sehingga sesuai untuk keperluan pemeriksaan dan pengobatan kasus infertilitas (Zavos et al., 1999).

Beberapa metode pengumpulan sperma dalam pemeriksaan analisis sperma yang sudah dapat diterapkan diantaranya dengan masturbasi, coitus interruptus dan coitus lengkap dengan menggunakan kondom sebagai penampung (Taylor and Martin, 1981). Metode yang paling dapat diterima dari berbagai penelitian sebelumnya adalah dengan masturbasi yang menunjukkan hasilnya lebih baik dari coitus interruptus (Sofikitis and Miyagawa 1993). WHO lebih merekomendasikan masturbasi namun adanya hambatan psikologis dan keyakinan yang dianut sebagian besar masyarakat di Indonesia maka coitus interruptus seringkali menjadi alternatif pengumpulan semen (Bahyah et al., 2010). Berdasarkan latar belakang tersebut maka penelitian ini bertujuan untuk mengetahui perbandingan kualitas sperma antara metode masturbasi dengan coitus interruptus.

\section{METODE PENELITIAN}

Penelitian dilakukan di Laboratorium Penunjang Infertilitas RSIA Bunda Arif Purwokerto pada bulan Januari 2017 - Juni 2018. Desain penelitian adalah observasional analitik dengan pendekatan cross sectional. Populasi penelitian adalah seluruh pasien infertil yang berobat di RSIA Bunda Arif Purwokerto Pada tahun 2017-2018. Sampel adalah pasien laki-laki infertil yang berobat di RSIA Bunda Arif Purwokerto periode Januari 2017-Juni 2018 Berjumlah 97. Data dikelompokkan menjadi dua kelompok berdasarkan metode pengambilan sampelnya, yaitu 72 sampel hasil masturbasi dan 25 sampel hasil coitus interruptus. Data pengambilan sampel sperma dengan cara lain seperti coitus lengkap dengan kondom, coitus interruptus yang dilakukan lebih dari 30 menit dan pemeriksaan re-analisis sperma setelah terapi dan riwayat varikokel dieksklusikan.

\section{Jalannya Penelitian}

\section{Pengumpulan Data}

Data diambil dari catatan rekam medik pasien laki-laki infertil yang melakukan pemeriksaan analisis sperma di Laboratorium Penunjang RSIA Bunda Arif Purwokerto periode Januari 2017-Juni 2018.

\section{Metode Analisis Sperma}

Pemeriksaan sampel sperma yang didapat ditampung dalam tabung kontainer dan langsung dilakukan analisis sperma dengan kriteria WHO (2010). Analisis sperma dilakukan oleh dokter dan analis terlatih meliputi pemeriksaan makroskopis dan mikroskopis yaitu volume, viskositas, konsentrasi, motilitas dan morfologi dan dibandingkan kualitas spermanya secara kuantitatif. 


\section{Analisis Data}

Data dianalisis dengan uji t tidak berpasangan. Data sekunder lain yang diambil meliputi umur pasien, jam kerja (jam/hari) dan riwayat merokok untuk diuji univariat.

\section{HASIL DAN PEMBAHASAN}

Dari data penelitian didapatkan hasil sebagai berikut :

Tabel I. Karakteristik responden

\begin{tabular}{lcc}
\hline \multicolumn{1}{c}{ Karakteristik } & Masturbasi & Coitus Interruptus \\
\hline Rerata umur pasien (tahun) & 34 & 37 \\
Rerata umur istri (tahun) & 31 & 34 \\
Jam kerja (jam/hari) & $10 \pm 4,64$ & $9 \pm 3,12$ \\
Merokok & & $11(11,30 \%)$ \\
- Ya & $51(52,60 \%)$ & $9(9,30 \%)$ \\
- Tidak & $26(26,80 \%)$ & 4 \\
- Riwayat & 20 & \\
\hline
\end{tabular}

Sumber : data sekunder terolah (2018)

Analisis statistik hasil pemeriksaan sperma yang diperoleh dari teknik masturbasi dan coitus interruptus dapat dilihat pada Tabel II.

Tabel II. Perbandingan analisis sperma antara masturbasi dan coitus interruptus

\begin{tabular}{lccc}
\hline Karakteristik & Masturbasi & Coitus Interruptus & $(\boldsymbol{p}<\mathbf{0 , 0 5})$ \\
\hline Konsentrasi (x10 $)$ & $46,50 \pm 7,20$ & $18,70 \pm 5,30$ & $0,04^{*}$ \\
Motilitas (\%/median) & & & \\
- Progresif & 29 & 27 & 0,63 \\
- Non progresif & 49 & 53 & 0,56 \\
• Immobile & 21 & 20 & 0,80 \\
Morfologi (\%/median) & & & \\
$\bullet \quad$ Normal & 3 & 2 & 0,72 \\
- Abnormal & 97 & 98 & 0,72 \\
\hline
\end{tabular}

Sumber : data Lab. RSIA Bunda Arif (2018)* = signifikansi

Tabel I menunjukkan beberapa karakteristik responden meliputi umur, jam kerja per hari dan status merokok. Tabel II menunjukkan perbedaan signifikan pada konsentrasi sperma antara teknik masturmasi dan coitus interruptus $(p<0,05)$. Meskipun secara statistik terdapat perbedaan yang signifikan namun kadarnya masih dalam batas normal (> $\left.15 \times 10^{6} / \mathrm{ml}\right)$. Pada parameter motilitas dan morfologi walaupun persentasenya lebih baik pada kelompok masturbasi namun tidak ada perbedaan signifikan secara statistik pada kedua kelompok. 
Parameter motilitas dan morfologi tidak menunjukkan perbedaan bermakna pada penelitian ini. Morfologi spermatozoa sangat penting karena merupakan indikator untuk menilai status epitel germinativumnya karena perubahan degenerasi yaitu penyempitan dan sklerosis lumen tubulus seminiferus dapat mengganggu spermatogenesis dan morfologi spermatozoa (Kidd et al, 2000). Hasil penelitian ini tidak sesuai dengan Bahyah et al., (2010) yang menunjukkan bahwa terdapat perbedaan yang signifikan dalam hal volume, konsentrasi, motilitas progresif dan morfologi normal dari spermatozoa yang dikumpulkan melalui coitus interruptus lebih baik jika dibandingkan dengan spermatozoa yang dikumpulkan melalui masturbasi. Sampel yang diperoleh dari coitus interruptus dapat meningkatkan rerata kehamilan melalui ART sehingga pengambilan sampel melalui coitus interruptus lebih disarankan.

Hasil penelitian Zavos et al., (1999) menunjukkan bahwa kebiasaan melakukan masturbasi ulang justru menurunkan volume semen dan jumlah spermatozoa tetapi motilitas dan morfologinya normal. Kualitas sperma yang baik pada pengambilan sampel melalui coitus interruptus menunjukkan bahwa penanda fungsi sekresi kelenjar prostat dan fungsional sperma lebih baik secara signifikan dibanding dengan masturbasi.

Studi yang menilai dampak usia laki-laki pada kesuburan seringkali dibiaskan oleh usia pasangan wanita dikarenakan wanita mengalami penurunan fekunditas secara alami. Penelitian Tietze (1957) yang meneliti tentang populasi Hutterite, sebuah sekte di Amerika Utara yang secara ketat menentang kontrasepsi sehingga berfungsi sebagai populasi yang ideal untuk mengamati perubahan kesuburan seiring bertambahnya usia, menunjukkan bahwa $11 \%$ wanita tidak subur pada usia 34 tahun, sebesar 33\% usia 40 tahun dan $87 \%$ usia 45 tahun. Fekunditas per siklus menurun dari $25 \%$ menjadi $30 \%$ per bulan pada awal hingga pertengahan 20 -an, hingga kurang dari 5\% pada usia 40 tahun (Harris et al., 2011).

Pada variabel mengenai umur laki-laki, penelitian Kidd et al (2000) menunjukkan bahwa umur berpengaruh terhadap status infertilitas. Saat menua, volume semen menurun karena insufisiensi vesikula seminalis yang menyumbang sebagian besar volume ejakulasi. Penuaan prostat menyebabkan atrofi otot polos dan penurunan kadar air serta protein yang mempengaruhi volume semen dan motilitas sperma. Penuaan pada epididimis mengganggu motilitas sperma menuju ke saluran reproduksi. Penuaan tidak hanya mempengaruhi kualitas sperma tetapi juga secara genetik merubah integritas sperma yaitu meningkatkan sperma aneuploidy dan meningkatkan mutasi germinal de novo (Kidd et al., 2000). Pada penelitian ini, rerata umur tidak masuk ke nilai ambang yang mempunyai risiko tinggi terjadi gangguan kualitas sperma.

Variabel merokok telah terbukti memiliki efek yang merugikan pada berbagai parameter analisis sperma. Penelitian metaanalisis menunjukkan adanya penurunan kualitas sperma baik pada laki-laki fertil maupun infertil dan terjadi penurunan konsentrasi sperma sampai 17\% pada laki-laki perokok dibanding laki-laki non perokok dan penurunan kualitas sperma ditemukan pada laki-laki perokok berat (20 batang rokok/hari) dan sedang (10-20 batang rokok/hari) dibanding perokok ringan (1-10 batang rokok/hari) (Durairajanayagan, 2018).

Penelitian cross-sectional dari 2542 laki-laki sehat dari 1987 hingga 2004 oleh RamlauHansen et al., (2007) menemukan bahwa perokok memiliki volume semen yang lebih rendah. Jumlah sperma dan persentase sperma motil dibandingkan dengan laki-laki yang tidak merokok dan pada laki-laki yang merokok lebih dari 20 batang per hari mengalami penurunan hingga 19\% dalam konsentrasi sperma dibandingkan dengan bukan perokok. Pada penelitian ini belum dapat menjabarkan hubungan antara merokok dengan perbandingan pengambilan sperma karena tidak dilakukan pertanyaan tentang jumlah batang rokok setiap hari dan tidak mempunyai kontrol dengan analisis sperma pada laki-laki fertil. 
Perilaku merokok berhubungan dengan lekositospermia, sumber endogen mayor reactive oxygen species (ROS) yang membebani pertahanan antioksidan endogen. Peningkatan kadar ROS di cairan semen mengakibatkan stress oksidatif pada spermatozoa yang mengganggu fungsi sperma dan berlanjut ke keadaan infertil (Durairajanayagan, 2018). Pada laki-laki perokok juga ditemukan adanya peningkatan fragmentasi DNA, kadar 8-oxo-2'-deoksiguanosin (basa mutagen) dan penurunan ekspresi checkpoint inase-1 (Chk-1) yang menurunkan kemampuan perbaikan sperma, meningkatkan apoptosis sperma dan penurunan kualitas sperma (Harlev, 2015). Secara umum, perilaku merokok yang mengganggu fertilitas laki-laki adalah meningkatnya stres oksidatif, kerusakan DNA dan apoptosis sel yang menyebabkan penurunan kualitas sperma, gangguan spermatogenesis dan fungsi sperma. Nikotin dalam rokok juga dapat menghambat sintesis testosteron yang menurunkan retara kadar testosteron serum (Durairajanayagan, 2018).

Pada penelitian ini menunjukkan bahwa terdapat perbedaan bermakna dalam hal konsentrasi sperma antara metode masturbasi dengan metode coitus interruptus $(p=0,04)$. Hal ini sesuai dengan penelitian Dehghani (2004) yang menunjukkan bahwa pengumpulan sperma melalui coitus interruptus tidak dianjurkan dalam program infertilitas. Metode pilihan untuk pengumpulan spermatozoa berkualitas tinggi dengan konsentrasi sperma imatur (sel spermatosit muda) rendah adalah melalui masturbasi dikarenakan sel bulat yang sangat berkaitan dengan spermatozoa muda atau leukosit yang dimungkinkan adanya onset awal infeksi yang dapat ditularkan saat berhubungan sehingga dapat mempengaruhi data. Namun, jika pasien menolak untuk menggunakan metode masturbasi, ejakulasi disarankan melalui penggunaan kondom nonspermicidal saat berhubungan. Akan tetapi hasil ini bertentangan dengan Gerris (1999) yang menunjukkan bahwa konsentrasi sperma lebih banyak pada pengambilan sampel metode coitus interruptus. Semen yang diproduksi secara alami selama proses hubungan seksual yang dihasilkan dengan metode coitus interruptus juga cenderung mempunyai kualitas dan kuantitas yang baik (Zavos et al., 1999).

Pengambilan sampel juga harus mempertimbangkan faktor psikologis yaitu kecemasan dan stres, misalnya lokasi pengambilan (rumah, klinik atau rumah sakit), keterbatasan ruang, ketidakhadiran istri, atmosfir rumah sakit, kebisingan yang semuanya dapat berhubungan secara negatif dengan kualitas semen (Elzanaty and Malm, 2008). Hasil penelitian ini dapat lebih dikembangkan dengan menambah jumlah sampel yang lebih besar dari berbagai ras dan randomisasi multisenter.

\section{KESIMPULAN}

Tidak terdapat perbedaan bermakna dalam hal morfologi dan motilitas sperma antara kelompok masturbasi dan coitus interruptus pada kasus infertilitas. Terdapat perbedaan bermakna dalam hal konsentrasi sperma antara kelompok masturbasi dan coitus interruptus pada kasus infertilitas.

\section{UCAPAN TERIMA KASIH}

Penulis mengucapkan terimakasih kepada Direktur RS Bunda Arif sebagai tempat penelitian dan pihak lain yang membantu selama penelitian. 


\section{DAFTAR PUSTAKA}

Bahyah, M.K., Murad, A.M.O.G., Roszaman, R., Ghazali, I., Roszaman, R., Nuraziana, A.W., et al. 2010. The outcome of the seminal fluid parameters collected via coitus interruptus versus masturbation. Med J Malyasia 65(1): 23-26.

Dehghani, V.A., Khalili, M.A., Zamani, N., Fakhri, D.F. 2004. Comparison between semen parameters of ejaculates collected via masturbation versus coitus interruptus. Iranian $J$ of Reprod Med 2(1): 9-11.

Durairajanayagam, D. 2018. Lifestyle causes of male infertility. Arab J of Uro 16: 10-20.

Elzanaty, S. \& Malm, J. 2008. Comparison of semen parameters in samples collected by masturbation at a clinic and at home. Fertil and Steril 89(6): 1718-22.

Gerris, J. 1999. Methods of semen collection not based on masturbation or surgical sperm retrieval. Hum Reprod Update 5(3): 211-215

Harlev, A., Agarwal, A., Gunes, S.O., Shetty,A., du Plessis, S.S. 2015. Smoking and male infertility: an evidence based review. World J Mens Health 33(3): 143-160.

Harris, I.D., Fronczak, C., Roth, L., Meacham, R.B., 2011. Fertility and the aging male. Rev Urol 13(4): 184-190.

Hinting, A. 2009. Penatalaksanaan pasangan infertil. Cermin Dunia Kedokteran 170(36): 4

Kidd, S.A., Eskenazi, B., Wyrobek, A.J. 2000. Effects of male age on semen quality and fertility: a review of the literature. Modern Trends 75(2): 237-247.

Ramlau-Hansen, C.H., Thulstrup, A.M., Aggerholm, A.S., Jensen, M.S., Toft, G., Bonde, J.P. 2007. Is smoking a risk factor for decreased semen quality? A cross-sectional analysis. Hum Reprod 22(1): 188-1.

Sofikitis, N.V., \& Miyagawa, I. 1993. Endocrinological, biophysical and biochemical parameters of semen collected via masturbation versus sexual intercourse. J Androl 14: 366-373.

Taylor, P.J., \& Martin, R.H. 1981. Semen analysis in the investigation of infertility. Canadian Fam Phys 27: 113-116.

Tietze, C. 1957. Reproductive span and the rate of conception among Hutterite women. Fertil Steril 8: 89-97.

World Health Organization. 2010. WHO laboratory manual for the examination of human semen and semen-cervical mucus interaction. Cambridge. Cambridge University press: 4-5. 
Zavos, P.N.Z., Zarmakoupis, C.N., Correa, J.R., Zavos, P.M. 1999. Multiple ejaculate collection via the use of a semen collection device at intercourse versus masturbation. Middle East Fertil Soc Journ 4(3): 228-232. 